\title{
Improved Employee Performance through Organizational Citizenship Behavior for the Environment (OCBE)
}

\author{
Fathia Ardiza ${ }^{1}$, Lenny C Nawangsari ${ }^{2}$, Ahmad Hidayat Sutawidjaya ${ }^{3}$ \\ \{fathyaardiza95@gmail.com¹, lenny.christina@mercubuana.ac.id², \\ a.h.sutawijaya@mercubuana.ac.id $\left.{ }^{3}\right\}$
}

Universitas Mercu Buana, Jakarta, Indonesia ${ }^{123}$

\begin{abstract}
This study aims to determine the effect of OCBE, Green Performance Appraisal, and Green Compensation on employee performance in two employee groups based on gender. This type of research is a quantitative approach using a survey method with a sample of 60 people. Data analysis using SEM with the Generalized Structural Component Analysis (GSCA) program. This study proves that OCBE, Green Performance Appraisal, and Green Compensation have an effect on employee performance in female employee groups. Whereas in the group of male employees the Green Performance Appraisal has no effect on Employee Performance.
\end{abstract}

Keywords: Green Performance Appraisal, Green Compensation and Rewards, OCBE; Employee performance

\section{Introduction}

In this digital era, companies are expected to continue to be innovative in managing management functions in order to increase their ability to compete. In the management of Human Resources, several strategies are implemented by the company to achieve optimal performance. HR is an important asset for a company that must be managed properly so that company goals can be achieved.

Based on the evaluation of KPI data for 3 years (2016-2018 period) in TELIN companies there was an increase in the number of workers who did not reach the target. After conducting a pre-survey on 20 employees, there were 3 biggest factors that were thought to affect performance, namely Green Performance Appraisal, Green Compensation and Reward and OCBE. Green Performance Appraisal plays an important role in the overall effort to improve performance, either at the individual or organizational level. Green Compensation and Rewards can be considered as potential tools to support environmental activities in organizations. OCBE is very important to improve employee performance on green environmental behavior in corporate organizations.

This study aims to examine the effect of the variable Green Performance Appraisal Green Compensation and Reward and OCBE on employee performance which is divided into 2 groups, namely the male group and the female group. The theory that underlies this research is: 


\subsection{Green Performance Appraisal}

Green Performance Appraisal can be defined as the extent to which certain employees engage in behavior (actions and activities) and produce results with respect to greening over a certain period of time [1]. Green Performance Appraisal is an employee performance appraisal of how well they are making progress towards a green environment [2].

\subsection{Green Compensation and Rewards}

Green Compensation and Rewards is a financial and non-financial reward system that aims to attract, retain and motivate employees to contribute to green environmental goals [3]

\subsection{OCBE (Organizational Citizenship Behavior for the Environment)}

The definition of OCBE is a social behavior of an individual and that is not explicitly recognized by formal reward systems and it contributes to a more effective environment of management by the organization. The dimensions in OCBE are Eco-initiatives, Eco-helping and Eco Civic Engagement [4].

\subsection{Employee Performance}

The definition of performance is what employees do or don't do [5]. Performance is also defined as a function of the interaction between ability and motivation so that performance $=$ $\mathrm{f}(\mathrm{A} \times \mathrm{M})$ [6]. Several previous studies related to the above topic stated that the Green Performance Appraisal which is applied as a system in the company has a positive effect on employee performance [7]. This study is in line with other research which states that the Green Performance Appraisal has an effect on performance [8]. Green Compensation and Rewards can be considered as potential tools to support environmental activities in organizations. [9] Related to research on OCBE, it was explained that OCBE has an effect on employee performance $[10,11]$.

Based on previous theory and research, the research hypothesis is presented as follows:

H1a: Green Performance Appraisal affects OCBE in male employee groups

H1b: Green Performance Appraisal affects OCBE in female employee groups

H2a: Green Compensation and Rewards affects OCBE in male employee groups

H2b: Green Compensation and Rewards has an effect on OCBE in female employee groups

H3a: Green Performance Appraisal affects Employee Performance in male employee groups

H3b: Green Performance Appraisal affects Employee Performance in female employee groups

H4a: Green Compensation and Rewards affect Employee Performance in male employee groups

H4b: Green Compensation and Rewards affects Employee Performance in groups of female employees

H5a: OCBE affects Employee Performance in male employee groups

H5b: OCBE affects Employee Performance in female employee groups

H6a: Green Performance Appraisal affects Employee Performance through OCBE for male employee groups

H6b: Green Performance Appraisal affects Employee Performance through OCBE for women

H7a: Green Compensation and Rewards affect Employee Performance through OCBE for male employee groups 
H7b: Green Compensation and Rewards affects Employee Performance through OCBE for female employees.

\section{Research Method}

This type of research is a quantitative study using a survey method. The research object at PT TELIN with a sample of 60 people. Data analysis used SEM with the Generalized Structural Component Analysis (GSCA) program.

\section{Results and Discussion}

Statistical analysis in this study used Generalized Structural Component Analysis (GSCA). The reason for using GSCA is by considering that the causal relationship formulated in this study uses a one-way (recursive) causality model with reflective variable measurements.

\subsection{Validity Test and Reliability}

\subsubsection{Discriminant validity}

Discriminant validity is a reflexive indicator measurement based on cross loading with its latent variables.

Table 1. Discriminant validity test results

\begin{tabular}{cc}
\hline \multicolumn{2}{c}{ Group 1 (Men's) } \\
\hline Variable & Average variance extracted (AVE) \\
\hline Green Performance Appraisal (X1) & 0,799 \\
Green Compensation and Rewards (X2) & 0,734 \\
OCBE (Y1) & 0,750 \\
Employee Performance (Y2) & 0,592 \\
Group 2 (Females) & Average variance extracted (AVE) \\
Green Performance Appraisal (X1) & 0,881 \\
Green Compensation and Rewards (X2) & 0,865 \\
OCBE (Y1) & 0,829 \\
Employee Performance (Y2) & 0,873 \\
\hline
\end{tabular}

The results of the discriminant validity test where all the Average variance extracted (AVE) values are greater than 0.50 so that it can be concluded that they meet the Discrimens validity requirements. 


\subsubsection{Composite Reliability}

Table 2. Composite Reliability Test Results

\begin{tabular}{ccc}
\hline & Group 1 (Men's) & \\
Variable & Composite Reliability & Description \\
Green Performance Appraisal (X1) & 0,949 & Reliable \\
Green Compensation and Rewards & & Reliable \\
(X2) & 0,924 & \\
OCBE (Y1) & 0,944 & Reliable \\
Employee Performance (Y2) & 0,927 & Reliable \\
Variable & Group 2 (Females) & \\
Composite Reliability & Description \\
Green Performance Appraisal (X1) & 0,973 & Reliable \\
Green Compensation and Rewards & 0,967 & Reliable \\
(X2) & 0,965 & Reliable \\
OCBE (Y1) & 0,985 & Reliable \\
\hline
\end{tabular}

The results of the composite reliability test show a satisfactory value, where all latent variables are reliable because all variable values have a composite reliability value $\geq 0.60$.

\subsection{Structural Equation Modeling}

This study uses a structural equation model of the GSCA approach. Before analyzing, first testing or evaluating the empirical research model. The results of testing the empirical model of this study can be seen in the image below:

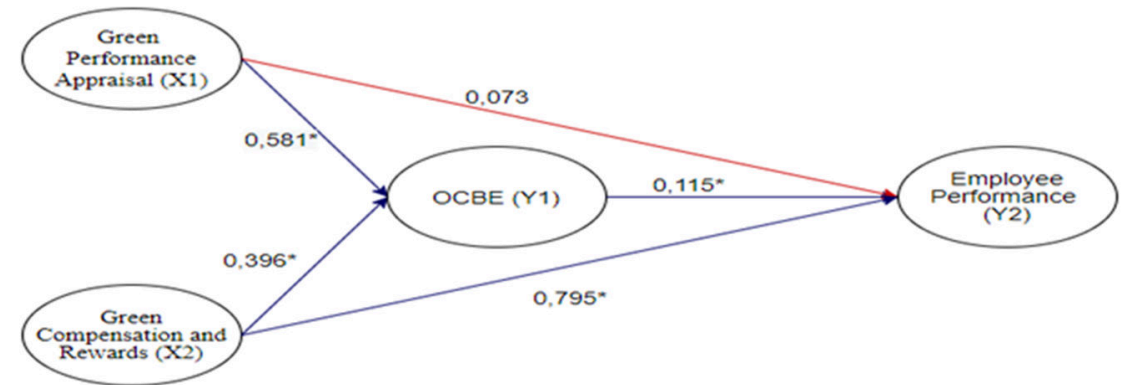

Fig 1. Results of Analysis with GSCA in Group 1 (Male) 


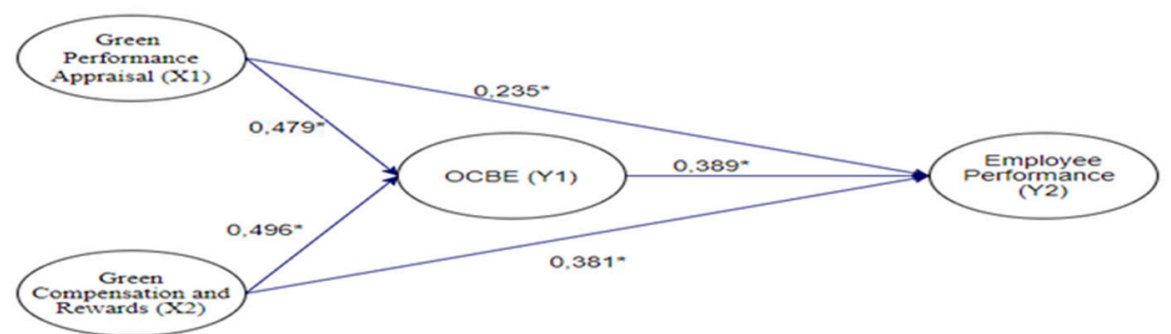

Fig 2. Results of Analysis with GSCA in Group 2 (female)

\subsection{Goodness of Fit Model}

The theoretical model in the research conceptual framework is said to be fit if it is supported by empirical data. There are two indications to see whether the model used is good, namely the goodness of fit of the structural model and the goodness of fit of the overall model. The results of testing the goodness of fit of the structural model and the overall model are in accordance with the results of the GSCA analysis. The hypothetical model, namely the goodness of fit overall model supported by empirical data, is presented in Table 3

Table 3. The Results of Goodness of Fit Overall Model Testing

\begin{tabular}{llll}
\hline Criteria & Cut-of value & Model Result & Description \\
\hline SRMR & $\leq 0,08$ & 0,08 & Model Good \\
GFI & $\geq 0,90$ & 0,933 & Model Good \\
\hline
\end{tabular}

The results of the Goodness of Fit Overall Model test based on Table 5.3 show that SRMR and GFI have met the cut off value, so the GSCA model in this study is suitable and suitable for use, so that interpretation can be made for further discussion.

\subsection{Variable Measurement Model}

The conversion of the path diagram into a measurement model for each variable (Green Performance Appraisal (X1), Green Compensation and Rewards (X2), OCBE (Y1) and Employee Performance (Y2)) can be seen in the table below.

Table 4. Variable Measurement Model Green Performance Appraisal (X1)

\begin{tabular}{llll}
\hline \multicolumn{4}{c}{ Group 1 (Men's) } \\
\hline Indicator & Estimate & SE & CR \\
\hline X1.1 & 0.895 & 0.002 & $478.3^{*}$ \\
X1.2 & 0.909 & 0.005 & $175.51^{*}$ \\
X1.3 & 0.948 & 0.005 & $187.21^{*}$ \\
X1.4 & 0.902 & 0.003 & $270.25^{*}$ \\
X1.5 & 0.868 & 0.049 & $17.61^{*}$ \\
X1.6 & 0.838 & 0.010 & $82.87^{*}$ \\
\hline \multicolumn{4}{c}{ Group 2 (Females) } \\
\hline X1.1 & 0.929 & 0.001 & $669.8^{*}$ \\
\hline X1.2 & 0.935 & 0.001 & $986.01^{*}$
\end{tabular}




\begin{tabular}{llll}
$\mathrm{X} 1.3$ & 0.933 & 0.010 & $92.8^{*}$ \\
$\mathrm{X} 1.4$ & 0.958 & 0.013 & $71.35^{*}$ \\
$\mathrm{X} 1.5$ & 0.940 & 0.003 & $335.45^{*}$ \\
$\mathrm{X} 1.6$ & 0.936 & 0.020 & $47.78^{*}$ \\
\hline
\end{tabular}

$\mathrm{CR}^{*}=$ significant at .05 level

Source: Primary data processed (2020)

The Green Performance Appraisal variable measurement model also informs that Indicator X1.3 has the largest loading factor value for group 1 and indicator X1.4 has the largest loading for group 2.

Table 5. Variable Measurement Model of Green Compensation and Rewards (X2)

\begin{tabular}{llll}
\hline \multicolumn{4}{c}{ Group 1 (Men's) } \\
\hline Indicator & Estimate & SE & CR \\
\hline X2.1 & 0.838 & 0.011 & $75.47^{*}$ \\
X2.2 & 0.886 & 0.026 & $33.59^{*}$ \\
X2.3 & 0.851 & 0.009 & $92.48^{*}$ \\
X2.4 & 0.828 & 0.041 & $20.24^{*}$ \\
X2.5 & 0.872 & 0.017 & $52.47^{*}$ \\
X2.6 & 0.863 & 0.001 & $1700.15^{*}$ \\
\hline & Group 2 (Females) & \\
\hline X2.1 & 0.914 & 0.029 & $31.28^{*}$ \\
X2.2 & 0.937 & 0.045 & $20.74^{*}$ \\
X2.3 & 0.930 & 0.008 & $122.37^{*}$ \\
X2.4 & 0.939 & 0.015 & $62.17^{*}$ \\
X2.5 & 0.938 & 0.032 & $29.0^{*}$ \\
X2.6 & 0.922 & 0.011 & $81.91^{*}$ \\
\hline
\end{tabular}

$\mathrm{CR}^{*}=$ significant at .05 level

Source: Primary data processed (2020)

The Green Compensation and Rewards variable measurement model also informs that Indicator X2.2 has the greatest loading factor value for group 1 and indicator X2.4 has the largest loading for group 2.

\begin{tabular}{llll}
\multicolumn{4}{c}{ Table 6. Measurement Model Variable OCBE (Y1) } \\
\hline Group 1 (Men's) \\
\hline Indicator & Estimate & SE & CR \\
\hline Y1.1 & 0.889 & 0.009 & $102.76^{*}$
\end{tabular}




\begin{tabular}{llll} 
Y1.2 & 0.888 & 0.025 & $36.26^{*}$ \\
Y1.3 & 0.915 & 0.017 & $52.72^{*}$ \\
Y1.4 & 0.910 & 0.002 & $558.55^{*}$ \\
Y1.5 & 0.874 & 0.003 & $258.86^{*}$ \\
Y1.6 & 0.720 & 0.003 & $209.12^{*}$ \\
Y1.7 & 0.851 & 0.007 & $114.75^{*}$ \\
\hline \multicolumn{4}{l}{ Group 2 (Females) } \\
\hline Y1.1 & 0.921 & 0.026 & $35.09^{*}$ \\
Y1.2 & 0.931 & 0.016 & $57.47^{*}$ \\
Y1.3 & 0.939 & 0.014 & $67.92^{*}$ \\
Y1.4 & 0.949 & 0.010 & $94.17^{*}$ \\
Y1.5 & 0.940 & 0.006 & $168.22^{*}$ \\
Y1.6 & 0.812 & 0.046 & $17.78^{*}$ \\
Y1.7 & 0.874 & 0.003 & $260.25^{*}$ \\
\hline CR* significant at .05 level \\
Source: Primary data processed (2020)
\end{tabular}

The OCBE variable measurement model also informs that the Y1.3 indicator has the largest loading factor value for group 1 and the Y1.4 indicator has the largest loading for group 2.

Table 7. Measurement Model Variable Employee Performance (Y2)

\begin{tabular}{llll}
\hline \multicolumn{4}{l}{ Group 1 (Men's) } \\
\hline Indicator & Estimate & SE & CR \\
\hline Y2.1 & 0.732 & 0.051 & $14.29^{*}$ \\
Y2.2 & 0.756 & 0.028 & $26.96^{*}$ \\
Y2.3 & 0.721 & 0.116 & $6.19^{*}$ \\
Y2.4 & 0.793 & 0.009 & $93.0^{*}$ \\
Y2.5 & 0.874 & 0.023 & $37.88^{*}$ \\
Y2.6 & 0.755 & 0.117 & $6.45^{*}$ \\
Y2.7 & 0.853 & 0.007 & $118.56^{*}$ \\
\hline Y2.8 & 0.740 & 0.007 & $102.68^{*}$ \\
Y2.9 & 0.753 & 0.043 & $17.58^{*}$ \\
Y2.10 & 0.739 & 0.036 & $20.33^{*}$
\end{tabular}




\begin{tabular}{lccc} 
Y2.11 & 0.732 & 0.081 & $9.05^{*}$ \\
\hline \multicolumn{4}{c}{ Group 2 (Females) } \\
Y2.1 & 0.806 & 0.074 & $10.88^{*}$ \\
Y2.3 & 0.942 & 0.032 & $29.23^{*}$ \\
Y2.4 & 0.943 & 0.031 & $30.69^{*}$ \\
Y2.5 & 0.948 & 0.020 & $46.45^{*}$ \\
Y2.6 & 0.947 & 0.018 & $51.47^{*}$ \\
Y2.7 & 0.955 & 0.012 & $82.73^{*}$ \\
Y2.8 & 0.966 & 0.021 & $45.71^{*}$ \\
Y2.9 & 0.959 & 0.017 & $56.25^{*}$ \\
Y2.10 & 0.956 & 0.032 & $29.47^{*}$ \\
Y2.11 & 0.923 & 0.049 & $18.73^{*}$ \\
\hline CR* = significant at .05 level & 0.019 & $49.5^{*}$ \\
Source: Primary data processed $(2020)$ &
\end{tabular}

The Employee Performance variable measurement model also informs that the Y2.5 indicator has the largest loading factor value for group 1 and the Y2.7 indicator has the largest loading for group 2.

\subsection{Hypothesis Testing Results (Structural Model Testing Results)}

In the structural model, nine hypotheses of the relationship between variables (direct influence) are tested. The complete results of testing the relationship between the research variables are presented in the table below.

Table 8. Research Hypothesis Testing Results (Direct Effect)

\begin{tabular}{clllll}
\hline Hypothesis & \multicolumn{1}{c}{ Direct Influence } & $\begin{array}{c}\text { Path } \\
\text { Coefficient }\end{array}$ & $\begin{array}{c}\text { Standard } \\
\text { Error }\end{array}$ & $\begin{array}{c}\text { Critical } \\
\text { Ratio }\end{array}$ & Description \\
\hline \multicolumn{3}{c}{ Male (Group 1) } \\
H1 & $\begin{array}{l}\text { Green Compensation } \\
\text { and Rewards -> OCBE }\end{array}$ & 0.396 & 0.137 & $2.9^{*}$ & Significant \\
H2 & $\begin{array}{l}\text { Green Performance } \\
\text { Appraisal -> OCBE } \\
\text { Green Compensation }\end{array}$ & 0.581 & 0.139 & $4.18^{*}$ & Significant \\
H3 & $\begin{array}{l}\text { and Rewards -> } \\
\text { Employee } \\
\text { Performance } \\
\text { Green Performance } \\
\text { Appraisal -> Employee }\end{array}$ & 0.795 & 0.070 & $11.38^{*}$ & Significant \\
H4 & $\begin{array}{l}\text { Performance } \\
\text { OCBE -> Employee } \\
\text { Performance }\end{array}$ & 0.115 & 0.070 & 1.04 & $\begin{array}{l}\text { Not } \\
\text { Significant }\end{array}$ \\
H5 & 0.006 & $20.57^{*}$ & Significant \\
\hline
\end{tabular}




\begin{tabular}{|c|c|c|c|c|c|}
\hline \multicolumn{6}{|c|}{ Females (Group 2) } \\
\hline $\mathrm{H} 1$ & $\begin{array}{l}\text { Green Compensation } \\
\text { and Rewards -> OCBE }\end{array}$ & 0.496 & 0.099 & $4.99 *$ & Significant \\
\hline $\mathrm{H} 2$ & $\begin{array}{l}\text { Green Performance } \\
\text { Appraisal -> OCBE }\end{array}$ & 0.479 & 0.095 & $5.03 *$ & Significant \\
\hline $\mathrm{H} 3$ & $\begin{array}{l}\text { Green Compensation } \\
\text { and Rewards -> } \\
\text { Employee } \\
\text { Performance } \\
\text { Green Performance }\end{array}$ & 0.381 & 0.002 & $165.17 *$ & Significant \\
\hline H4 & $\begin{array}{l}\text { Appraisal -> Employee } \\
\text { Performance }\end{array}$ & 0.235 & 0.095 & $2.48 *$ & Significant \\
\hline H5 & $\begin{array}{l}\text { OCBE -> Employee } \\
\text { Performance }\end{array}$ & 0.389 & 0.093 & $4.18^{*}$ & Significant \\
\hline
\end{tabular}

$\mathrm{CR}^{*}=$ significant at .05 level

Source: Primary data processed (2020)

The results of the analysis show that all the relationships between variables on the direct effect show significant results, but there is one direct effect that is not significant, namely the relationship between the Green Performance Appraisal on the Employee Performance in the Male Group. The indirect effect is stated as significant if the two direct effects that form it are significant, if one or both of them are not significant then the indirect effect is not significant. The following shows the results of the indirect effect.

Table 9. Research Hypothesis Testing Results (Indirect Influence)

\begin{tabular}{|c|c|c|c|c|}
\hline Hypothesis & Relationship & Coefficient & Description & Conclusion \\
\hline \multicolumn{5}{|c|}{ Male (Group 1) } \\
\hline H6 & $\begin{array}{l}\text { Green Compensation } \\
\text { and Rewards -> } \\
\text { OCBE -> Employee } \\
\text { Performance }\end{array}$ & 0.046 & $\begin{array}{l}\text { Green Compensation and } \\
\text { Rewards -> OCBE (Sig.), } \\
\text { OCBE -> Employee } \\
\text { Performance (Sig.) }\end{array}$ & Significant \\
\hline $\mathrm{H} 7$ & $\begin{array}{l}\text { Green Performance } \\
\text { Appraisal -> OCBE - } \\
>\text { Employee } \\
\text { Performance }\end{array}$ & 0.067 & $\begin{array}{l}\text { Green Performance } \\
\text { Appraisal -> OCBE } \\
\text { (Sig.), } \\
\text { OCBE -> Employee } \\
\text { Performance (Sig.) }\end{array}$ & Significant \\
\hline \multicolumn{5}{|c|}{ Females (Group 2) } \\
\hline H6 & $\begin{array}{l}\text { Green Compensation } \\
\text { and Rewards -> } \\
\text { OCBE -> Employee } \\
\text { Performance }\end{array}$ & 0,193 & $\begin{array}{l}\text { Green Compensation and } \\
\text { Rewards -> OCBE (Sig.), } \\
\text { OCBE -> Employee } \\
\text { Performance (Sig.) }\end{array}$ & Significant \\
\hline $\mathrm{H} 7$ & $\begin{array}{l}\text { Green Performance } \\
\text { Appraisal -> OCBE - } \\
>\text { Employee } \\
\text { Performance }\end{array}$ & 0,186 & $\begin{array}{l}\text { Green Performance } \\
\text { Appraisal -> OCBE } \\
\text { (Sig.), } \\
\text { OCBE -> Employee } \\
\text { Performance (Sig.) }\end{array}$ & Significant \\
\hline
\end{tabular}

Source: Primary data processed (2020) 
The results of testing the indirect effect of the structural model and obtained significant results in Group 1 and Group 2.

\subsection{Discussion \\ 3.6.1 Green Performance Appraisal affects OCBE.}

The results of the study proved that the Green Performance Appraisal had an effect on OCBE in both groups. This indicates that the higher the Green Compensation and Rewards, the higher the OCBE. In the Green Performance Appraisal for groups of male employees in the object of this study, they feel that their involvement in environmental problems and the greening system is quite well implemented. Meanwhile, the female employee group felt an understanding of green environmental behavior and the greening system in the workplace.

\subsubsection{Green Compensation and Rewards affect OCBE.}

This study proves that the Green Performance Appraisal has a significant effect on OCBE in both groups. This indicates that the higher the Green Performance Appraisal, the higher the OCBE. In Green Compensation and Rewards, the group of male employees considered that there was fairness in their payroll and they considered that the difference in wages between parts of the company had met expectations. Meanwhile, the female employee group felt that employees would get certain Compensation \& Rewards if they contributed ideas and organized an event about green environment.

\subsubsection{Green Performance Appraisal affects Employee Performance.}

This study proved different results for the two groups. In the male employee group the Green Performance Appraisal has no effect on Employee Performance. Meanwhile, in the group of female employees the Green Performance Appraisal has an effect on Employee Performance. The results of the study indicate that what needs to be improved is the implementation of the Green Performance Appraisal in the workplace for male employee groups. Meanwhile, the group of female employees felt that there was a need for improvement on long-term and short-term strategies regarding employee performance and assisting in planning the performance and skills of employees in the future.

\subsubsection{Green Compensation and Rewards affect Employee Performance.}

Research results prove Green Compensation and Rewards for Employee Performance. In both groups it was proven that it indicates that the higher the Green Compensation and Rewards, the higher the Employee Performance. The male group in this study informed that what needs to be improved regarding Green Compensation and Rewards is so that management can motivate employees to be able to contribute ideas and organize an event about green environment. Meanwhile, the women's group stated that what the company had to improve was the existence of a good Green Compensation \& Rewards system for employees to have a caring attitude towards the green environment.

\subsubsection{OCBE affects Employee Performance.}

This study proves that OCBE has an effect on Employee Performance. This indicates that the higher the OCBE, the higher the Employee Performance for both male employees and female employees. In the research object, the male group informed that the dominant thing in employee behavior is the employee's habit of storing used paper and will reuse it if one day is needed. Meanwhile, what needs to be improved is the desire of employees to encourage colleagues and express ideas / opinions about environmental problems. The women's group 
stated that the CSR program related to greening the environment was quite well implemented. Meanwhile, according to them, what needs to be improved is the active participation in environmental events organized by the Company.

\subsubsection{Green Performance Appraisal affects Employee Performance through OCBE.}

This study proves that Green Performance Appraisal has an effect on Employee Performance and OCBE plays a role in strengthening the relationship between the Variable Green Performance Appraisal and Employee Performance. According to the men's group regarding Employee Performance, what needs to be improved is to improve work results that can be received by superiors and colleagues. Meanwhile, the women's group that needs to be improved by workers is the accuracy of workers in carrying out their work.

\subsubsection{Green Compensation and Rewards affect Employee Performance through OCBE.}

The research results prove that Green Compensation and Rewards have an effect on Employee Performance and OCBE plays a role in strengthening the relationship between Green Compensation and Rewards on Employee Performance in both groups of workers. The male group in the research object stated that the dominant thing related to Employee Performance is that employees are working efficiently. Meanwhile, the women's group stated that the employees had done their job well

\section{Conclusions}

In conclusion that the Green Performance Appraisal; Green Compensation and Rewards and OCBE have an effect on Employee Performance, except for the male group that the Green Performance Appraisal has no effect on Employee Performance. Suggestions for organizations related to research results are Green Performance Appraisal and Green Compensation \& Rewards system that is more integrated in the HR management system. And the existence of a program to motivate employees to have a green environmentally caring behavior in the workplace. For further researchers, it is hoped that they can explore other variables related to company sustainability that affect OCBE and employee performance.

\section{References}

[1] A. Anton Arulrajah.2016.Green Human Resource Management Practices: A Review. Sri Lankan Journal of Human Resource Management 5(1):1-16

[2] Pavitra Mishra, (2017) "Green human resource management: A framework for sustainable organizational development in an emerging economy", International Journal of Organizational Analysis, Vol. 25 Issue: 5, pp.762-788

[3] Rael Jeruto Mandago. 2018. Influence Of Green Reward And Compensation Practice On Environmental Sustainability In Selected Service Based State Corporations In Kenya. European Journal Of Business And Strategic Management ISSN 2518-265X (Online)Vol.3, Issue 6, No.1, Pp 1 - 12, 2018

[4] Boiral dan Paille. (2012). Organizational Citizenship Behaviour for the Environment:. J Bus Ethics , 109:431-445

[5] Mathis, R.L. \& J.H. Jackson. (2006). Human Resource Management: Manajemen Sumber 
Daya Manusia. Edisi Ketiga. STIE YPKN. Yogyakarta

[6] Robbins, P. Stephen dan Mary Coulter. (2012). Manajemen. Erlangga. Jakarta

[7] Tulasi Das, V., \& Sreedhar Reddy, B. (2016). Employee perception towards green HRM: An investigative study. EPRA International Journal of Economic and Business Review, 4(9), 101112.

[8] Nury Ariani Wulansari, Rini Setyo Witiastuti, and Siti Ridloah.2018.Employee Performance Measurement Development based on Green HRM Indicators. CE-BEES 2018 International Conference on Economics, Business and Economic Education 2018 Volume 2018

[9] Pascual Berrone Luis R.Gomez-Mejia.2009. Environmental Performance And Executive Compensation: An Integrated Agency-Institutional Perspective.The Academy Of Management Journal 52(1):103-126

[10] Jennifer L Robertson, Julian Barling. 2017.Toward a new measure of organizational environmental citizenship behaviour.Journal of Business Research. volume 75,June 2017, Pages 57-66

[11] Nawangsari, Lenny C. \& Ahmad H Sutawijaya. (2019). Green Human Resources Management in Era Industri 4.0 at University. International Journal of Economics, Business and Management Research. (3) 8, pp: 83-90. 